\title{
From Human Smuggling to State Capture: Furthering Neoliberal Governance in North Africa
}

\author{
Matteo Capasso \\ Robert Schuman Centre for Advanced Studies, European \\ University Institute, Florence, Italy \\ matteo.capasso@eui.eu
}

\begin{abstract}
When examining the issue of human smuggling and its facilitating practises, mainstream IR analyses emphasize its criminal and illegal aspects. Such securocratic interpretations, largely mirroring EU concerns over migration, have managed to crowd-out alternative explanations of this phenomenon, detaching it from issues of capital and class. Drawing on fieldwork and secondary sources, this paper argues that people's involvement in the facilitation of human smuggling in Tunisia has emerged because of the increasing precariousness of labor and life. Precarity, however, is not the result of weak and failing institutions; rather it should be understood in relation to the subordinate integration of Tunisia into the global neoliberal economy. In such a context, the EU's insistence on policies based on border security and free-trade agreements securitises the lives of the poor to serve wealthy regional and European elites, thus furthering neoliberal governance in North Africa.
\end{abstract}

\section{Keywords}

EU - migration - imperialism - neoliberalism - North Africa - smuggling - state capture - Tunisia

There has been an increased interest in examining informal and border-land economies in the MENA region, given their strategic role and geopolitical 
relevance to EU-bound irregular migration. ${ }^{1}$ Work examining practices like fuel smuggling, ${ }^{2}$ trade in weapons, ${ }^{3}$ drugs, ${ }^{4}$ and migrant smuggling ${ }^{5}$ has emerged in recent years. Involvement or participation in these economies, however, has most often been framed through a Western security lens. ${ }^{6}$ Securocratic ${ }^{7}$ scholarship have opted to contextualize the involvement in informal economies-primarily of young men from the Global South-as a gateway into activities like terrorism and transnational organized crime. ${ }^{8}$ There is a vast body of literature examining the presence of jihadists, radicalized youth, transnational criminal networks, and militias in the MENA region, which alleges connections between their activities ${ }^{9}$ and informal forms of trade. ${ }^{10}$ Therefore, a vast range of informal market activities have found themselves defined or catalogued as posing risks to EU security. The notion of informality as carrying potential security implications (most often in the form of irregular migration

$1 \quad$ Malik, A. and M. Gallien. "Border Economies of the Middle East: Why Do They Matter for Political Economy?” Review of International Political Economy 27 (3) (2019), 732-762.

Eaton, T. Libya's War Economy: Predation, Profiteering and State Weakness (London: Chatham House, 2018); Megerisi, T. "Egypt, Algeria, Tunisia. Neighboring States Diverging Approaches.” In Foreign Actors in Libya's Crisis, eds. K. Mezran and A. Varvelli (Milano: ISPI, 2017), 23-39.

3 Kartas, M. On the Edge? Trafficking and Insecurity at the Tunisian-Libyan Border (Geneva: Small Arms Survey Graduate Institute of International and Development Studies, 2014).

4 Raineri, L. "The Collateral Damage of the War on Smugglers along the Central Mediterranean Route" in Migration in West and North Africa and across the Mediterranean (Brussels: IOM, 2020); Micallef, M. "People Smuggling in Post-Revolution Libya." In People Smugglers Globally eds. J. Coyne and M. Nyst (Barton, ACT: Australian Strategic Policy Institute, 2017), 38-43.

T. Reitano, M. Shaw, and L. Adal eds. Smuggled Futures: The Dangerous Path of a Migrant from Africa to Europe (Geneva: Global Initiative against Transnational Organized Crime, 2014); Micallef, M. and T. Reitano, The Anti-Human Smuggling Business and Libya's Political End Game (Geneva: Global Initiative against Transnational Organized Crime, 2017).

6 Ben Yahia, J. and I. Van Zyl. "Organised Crime Meets Terrorism in Tunisia." ISS Africa (7 May 2019); Scheele, J. Smugglers and Saints of the Sahara: Regional Connectivity in the Twentieth Century. (Cambridge: Cambridge University Press, 2012); Baird, T. Human Smuggling in the Eastern Mediterranean (London: Routledge, 2016).

7 I use the word 'securocratic' to refer to those analyses in IR and security studies that accentuate the criminal and illegal aspects of migration and migrants' smuggling.

8 Spike Peterson, V. 'Gendering Insecurities, Informalization and "War Economies." In The Palgrave Handbook of Gender and Development: Critical Engagements in Feminist Theory and Practice, ed. W. Harcourt (London: Palgrave Macmillan, 2016), 441-462.

9 International Crisis Group. Tunisia's Borders: Jihadism and Contraband (Brussels: International Crisis Group, 2013).

10 Reitano, T. and M. Shaw, and C. Neilleman. "Libya: Criminal Economies and Terrorist Financing in the Trans-Sahara" Policy Brief Global Initiative (2015), available online at https://globalinitiative.net/analysis/libya-criminal-economies-and-terrorist-financing-inthe-trans-sahara/ (accessed 28 January 2021); Eaton. Libya's War Economy. 
and terrorism) has in this sense shaped the EU's research and policy agenda, as well as budget allocations concerning research, security and development. In the case of Tunisia, many authors have claimed that widespread precarity and underdevelopment has allowed terrorist organizations to successfully establish themselves in remote communities, where they recruit disillusioned and naïve young Tunisians - in particular, young males - to work in illicit markets and activities which, if unmonitored, could bring devastating consequences for the security of the region, the country, and most importantly the EU.11

Focusing on the issue of facilitation of human smuggling, I argue that the IR and security literature reflect the class position of Western imperial capital. Firstly, as Sanchez argues, this literature has systematically relied on racialized, gendered portrayals of youth in the MENA, depicting them as naïve and unassertive young men who are nevertheless potentially lethal, if trained. ${ }^{12}$ These interpretations coincide with a wider political attempt to transform migration into a 'cultural threat,'13 thus no longer conceptualized in class terms. Facing this constant threat of (un)assimilable and dangerous 'Others' coming to the shores of Europe, increasing security appears as the most obvious and natural response. ${ }^{14}$ More importantly, I argue that such securocratic narratives align with liberal political economy analyses presenting the socio-economic maladies of countries of the Global South as a problem of state capture, where private and public actors collude and rely on the systematic abuse of formal institutions in order to accumulate power and wealth. According to this literature, state capture emerges due to a failed and corrupted process of liberalization, thus reflecting a late-developmental syndrome.

Against this backdrop, I argue that the facilitation of human smuggling and state capture are two interrelated mechanisms, both linked to the process of unequal exchange. As much as precariousness of labor and life drives

Fahmi, G. and H. Meddeb. Market for Jihad: Radicalization in Tunisia (Washington, D.C: Carnegie Endowment for International Peace, 2015); Djallil, L. "The Tunisian Jihad: Between al-Qaeda and Isıs", Middle East Policy, 26(1) (2019), 97-116; Zelin, A. Y. Your Sons Are at Your Service: Tunisia's Missionaries of Jihad (New York, NY: Columbia University Press, 2020); Boukhars, A. "The Potential Jihadi Windfall from the Militarization of Tunisia's Border Region with Libya", Combating Terrorism Center at West Point (2018), available online at https://ctc.usma.edu/potential-jihadi-windfall-militarization-tunisiasborder-region-libya/ (accessed 28 January 2021). European University Institute, 2019); Sanchez, G. "Women's Participation in the Facilitation of Human Smuggling: The Case of the US Southwest" Geopolitics 21 (2) (2016), 387-406. Yilmaz, F. How the Workers Became Muslims: Immigration, Culture, and Hegemonic Transformation in Europe (Ann Arbor, MI: University of Michigan Press, 2016). van Munster, R. Securitizing Immigration: The Politics of Risk in the EU. (London: Palgrave Macmillan, 2009). 
people's participation in human smuggling, this should be understood vis-à-vis the increasing pauperization of the economies of countries of the Global South, which allows, in turn, Western global primacy to continue. ${ }^{15}$ I present this argument by dividing it in three main sections. In the first part, I show that - contrary to securocratic narratives - the facilitation of human smuggling is a mechanism to reduce the impact of inequality and disenfranchisement in Tunisia. Faced with less income-generating options, an increasing number of people turn to informal economies, including facilitation of human smuggling, as a form of day-to-day survival. In the second part, I connect the emergence of the widespread pauperisation to these analyses that frame its existence as the result of poor governance mechanisms, recentring the debate around the process of unequal exchange. In other words, I demonstrate how the ongoing pauperisation of the Tunisian economy relates to its subordinate integration into the global neoliberal one. In the last section, I conclude by assessing current EU policies based on border security and free-trade agreements as part-and-parcel of its wider attempts to further neoliberal governance in North Africa. By securitising the lives of the poor, these policies continue to serve wealthy regional and European elites, thus the power of Western neoliberal capital. Any serious attempt to undo these dynamics requires us to rethink the neoliberal terms of engagement that have so far dictated the political and economic agenda between the North and South of the world.

\section{Facilitation of Human Smuggling: Between Survival and Precarity ${ }^{16}$}

Throughout the ethnographic work ${ }^{17}$ carried out in Tunisia and along the border it shares with Libya, ${ }^{18}$ encounters with multiple stakeholders (personnel from international NGOS, civil society, policy-makers and law enforcement bodies)

Amin, S. Unequal Development: An Essay on the Social Formations of Peripheral Capitalism (London: Monthly Review Press, 1976); Kadri, A. Arab Development Denied: Dynamics of Accumulation by Wars of Encroachment (London: Anthem Press, 2015); Lauesen, T. The Global Perspective: Reflections on Imperialism and Resistance. (Montreal, QC: Kersplebedeb, 2018).

16 For this section a particular acknowledgement goes to Gabriella Sanchez.

17 The data were gathered during $2018-2020$, as part of the EU-funded Horizon 2020 EU-LISTCO project. Fieldwork was undertaken in Tunis and across the Libyan-Tunisian border, while Interviews were undertaken with local inhabitants, practitioners working for international organizations (including IOM and EU) and local politicians. Further data was collected during closed meetings, both in-person and online, with policy makers and practitioners. 
have confirmed the existence of concern over the potential radicalization of local youth through their involvement in activities like fuel or migrant smuggling. However, only few admitted that youth may be inclined to join groups promoting a specific ideology. ${ }^{19}$ More importantly, fieldwork data revealed a more nuanced, grounded understanding of this dynamic, suggesting that most involvement in informal markets (including the facilitation of human smuggling, thus migrants) is primarily driven by the lack of income-generating options, rather than by ideological aspirations or affiliations. Interlocutors emphasized how the involvement in informal markets tended to counter the effects of unemployment, poverty, lack of education, or other occupational options. In short, our data reflected that involvement in informal economies of the kinds often examined in security narratives (i.e., those involving criminalized and allegedly terrorist activities) had a tendency to be short-lived even if quite sought-after. For informal economies often provided "structures of possibility, spaces of solidarity, order and alternative social worth." ${ }^{20}$ Political or ideological aspirations did not drive people to join informal economies; rather the existence of structural inequalities, compounded by unemployment and disenfranchisement across Tunisia drives the participation of vast and increasing segments of the population ${ }^{21}$ in the facilitation of human smuggling. As Hamza Meddeb ${ }^{22}$ has argued, it is the existence of economic inequalities and the need to fulfil immediate material needs that pushes people to participate into these informal economies. In this sense, smuggling is a strategy articulated from below, allowing disenfranchised communities to generate an income and foster their own economies and local forms of development, and increasing migrant opportunities for mobility.

In particular, our data suggest that facilitators operate in their own communities, coming together on demand, and most often facilitating the irregular journeys of people known to them through social ties, or their own journeys. As documented by other studies, ${ }^{23}$ it is possible to affirm that facilitators participate in the facilitation of migrant journeys either independently (that is, lacking

19 Boukhars, "The Potential Jihadi Windfall."

$20 \quad$ Jensen, S. and H. Vigh, Sporadically Radical: Ethnographies of Organized Violence and Militant Mobilization (Copenhagen: Museum Tusculanum Press, 2018), 39.

21 Tababy, K. "The Dynamics of Irregular Migration in Tunisia: An Attempt to Read the Migration Landscape during the Pandemic." In State Policies and the Most Marginalised ed. S. Jaballah (Tunis: Forum Tunisienne por les Droits Economique et Sociaux, 2020) (in Arabic).

Meddeb, H. "L'Ambivalence de La Course à 'El Khobza': Obéir et Se Révolter En Tunisie" Politique Africaine 121 (2011), 35-51; Meddeb, H. Young People and Smuggling in the Kasserine Region of Tunisia (London: International Alert, 2016). 
network-like ties), or in a fashion reflective of community, tribal, or clan ties. Historically, many of these activities have been performed for generations, for the goal of supporting their own livelihoods, put at risk by socio-economic inequality and militarization. Findings indicate that, without exception, participation in human smuggling generated jobs and income across often disenfranchised and impoverished communities, while simultaneously providing the opportunities migrants needed to continue or embark on their journeys. ${ }^{24}$ On the one hand, most smuggling facilitators were in fact local people severely impacted by the marginalization of their communities and the lack of viable employment options, who opted to participate in smuggling as an income-generating strategy with slim returns. On the other, migrants often volunteered or purposely sought opportunities to support smuggling operations to offset the cost of their own journey, or if stranded or unemployed, to obtain cash or in-kind payment. This strategy also appeared to be the result of the lack of permanent, steady jobs for migrants, but also of scant cash flow.

Remarkably, the facilitation of irregular migration in Tunisia does not appear to have the same social clout as the facilitation of other forms of irregular or informal trade (namely fuel, weapons, or drugs). In fact, the smuggling of migrants lacks the reputation and political weight of other forms of smuggling and/or illicit trade like fuel, for example, for it to be considered a security threat. Despite the fact that mainstream IR and security accounts on the operation of smuggling tend to emphasize their inherent criminal or exploitative nature, these practices typified as migrant smuggling are not new. In line with the work of other scholars in the region, ${ }^{25}$ people's participation in trade and mobility practices - and, in particular, the kinds facilitated by tribal, pastoral, and migrant groups- have become increasingly criminalized through the introduction of EU attempts and initiatives to curtail irregular migration. The most emblematic example to counter smuggling lies in the implementation of the EU Trust Fund for Africa (EUTF), ${ }^{26}$ whose goal is to address "the root causes of instability, forced displacement and irregular migration and to

Al-Arabi, A. "Local Specificities of Migration in Libya : Challenges and Solutions." Policy Brief Middle East Directions (Florence: European University Institute, 2018); Achilli, L. "The 'Good' Smuggler: The Ethics and Morals of Human Smuggling among Syrians." The Annals of the American Academy of Political and Social Science 676 (1) (2018), 77-96.

Sanchez, Beyond Militias and Tribes; Brachet, J. "Manufacturing Smugglers: From Irregular to Clandestine Mobility in the Sahara." The Annals of the American Academy of Political and Social Science 676 (1) (2018), 16-35; Richter, L. "Doing Bizness: Migrant Smuggling and Everyday Life in the Maghreb." Focaal 85 (2019), 26-36. 
contribute to better migration management" by "stepping up the fight against smugglers and traffickers and increased cooperation with Egypt, Tunis and Algeria - preventing irregular migration and the displacement of routes."27 The Trust dedicates at least a third of its funds to counter migrant smuggling and human trafficking through the strengthening of border guards and policing institutions. ${ }^{28}$ As part of the Fund, 15 million euros have been assigned to the creation of a joint regional initiative between the EU and UNODC under the project 'Dismantling the Criminal networks operating in North Africa and involved in migrant smuggling and human trafficking. ${ }^{29}$ Once again, the funds are supposed to strengthen the capabilities of law enforcement, border and police officers in tackling smuggling cases. In a similar fashion, EU member states and non-like Germany and the UK-have also dedicated a lot funds to strengthen the security sector of Tunisia after 2011. The empowerment of the security sector and the army is seen as key to "contribute directly to the fight against illegal migration" while having a "positive influence on migration dialogues and readmission-issues with other states." ${ }^{30}$

The adoption of demands and the implementation of programs and initiatives to counter informal practices have, however, had scant impact on their occurrence. ${ }^{31}$ In fact, many of the displays of power and control deployed to

In Beyond Networks, Militias and Tribes: Rethinking EU Counter-Smuggling Policy and Response ed. G. Sanchez (Brussels: EuroMeSCo Policy Study, forthcoming).

European Commission. Joint Communication to the European Parliament, the European Council and the Council: Migration on the Central Mediterranean Route: Managing flows, saving lives (25 January 2017), available online at https://eur-lex.europa.eu/legal-content/ GA/ALL/?uri=CELEX\%3352017JCooo4 (accessed 28 January 2021).

European Trust Fund for Africa. Factsheet: the EU Emergency Trust Fund for stability and addressing root causes of irregular migration and displaced persons in Africa. (2020), https:// ec.europa.eu/trustfundforafrica/sites/euetfa/files/factsheet_eutf-for-africa_october_2020. pdf (accessed 28 January 2021).

29 European Union. "Dismantling the criminal networks operating in North Africa and involved in migrant smuggling and human trafficking. Action Fiche of the EU Trust Fund to be used for the decisions of the Operational Committee. Annex IV to the agreement establishing the European Union Emergency Trust Fund for stability and addressing root causes of irregular migration and displaced persons in Africa and its internal rules." (2018), available online at https://ec.europa.eu/trustfundforafrica/sites/euetfa/files/to5-eutf-noa-reg-o5. pdf (accessed 28 January 2021).

Walsh, A. and J. Treffler. "What Is Germany Bringing to Tunisia's Security Sector?" Middle East Institute (13 August 2019), available online at https://www.mei.edu/publications/ what-germany-bringing-tunisias-security-sector\#_ftn17 (accessed 28 January 2021).

In response to EU expectations in tackling irregular migration, the Tunisian government passed the Organic Law 2004-6 in February 2004. While the law condemns 'whoever facilitates, helps, or organizes in any manner whatsoever, even for free, the illegal 
create a sense of authority often contribute to what scholars have referred to as the 'spectacle of illegality.'32 Checkpoints, patrols, and surveillance posts in Libyan and Tunisian locations were often located right next to dozens of stands where smuggled fuel was sold, for example. From the perspective of our respondents, involvement in informal practices constituted a direct response to the precariousness of life and labour, whose criminalization has been part of the drastic attempts by political elites to comply with external demands (primarily those of the EU) for security, enforcement, and control.

In Tunisia, the effectiveness of securitizing efforts appears to be impacted also by the belief on the part of law enforcement that informality and irregular migration are the only option many Tunisians have. ${ }^{33}$ Furthermore, most migrant smuggling activities occur in remote parts of the country, away from scrutiny and socially accepted by community residents and local political and social leaders. Stakeholders indicated that for the current government, like under the Ben Ali regime, involvement in smuggling is a socially constructed necessary evil. In this regard, as interviewed stakeholders indicated, Tunisian law enforcement often allows boats carrying migrants simply to depart from Tunisian coasts, knowing that those on board have scant opportunities available to them should they remain in-country. The 2011 revolt and the current Covid-19 pandemic, in fact, have not stopped Tunisians from migrating. ${ }^{34}$ For instance, the fishermen's situation has deteroriated after 2011 because the control and regulation of fishing have been suspended. ${ }^{35}$ Consequently, many small fishermen had to sell their boats and attempt to migrate or find other jobs because they could not compete with the bigger commercial boats fishing

entry or exit of a person out of the Tunisian territory, by land, sea or air transport,' its implementation remains ambiguous at best. For a discussion, see Cassarino, J.P. "Channelled Policy Transfers: EU-Tunisia Interactions on Migration Matters." European Journal of Migration and Law 16 (1) (2014), 97-123. De Genova, N. "Spectacles of Migrant 'Illegality': The Scene of Exclusion, the Obscene of Inclusion." Ethnic and Racial Studies 36 (7) (2013), 1180-1198.

33 Sanchez, Beyond Militias and Tribes.

34 Tababy, "The Dynamics of Irregular Migration in Tunisia"; Foroudi, L. "Covid-19 Fallout Drives Tunisians to Italy despite Deportations", The New Humanitarian (1 September 2020); Foroudi, L. "The Sea Is Dead." The New Humanitarian (14 September 2020). The deteriorating situation of fishermen is also linked to the effects of climate change, shown in the case of the oil spill in Kerkennah, see Hamouchene, H. "Kerkennah: On the Frontline of Resistance to the Fossil Fuel Industry in Tunisia." Committee for the Abolition of Illegitimate Debt (2016), available online at https://www.cadtm.org/Kerkennah-on-thefrontline-of (accessed 28 January 2021). 
in their zones. ${ }^{36}$ Moreover, the gradual destruction of Libya ${ }^{37}$ has further reduced the economic opportunities for Tunisian migrant labour, increasing the importance of the informal economy in Tunisia.

To understand the causes of increasing economic and social precarity unfolding in Tunisia, further revealed by the ongoing protest in the country since mid-January 2021, it is crucial to discuss the structural forces at play that produce this outcome. While critical anthropological work ${ }^{38}$ has highlighted the nuanced experiences of people involved in human smuggling, there remains a strong need to link these micro-experiences to the neoliberal structure of the global economy. ${ }^{39}$ Otherwise, while studying a portion of a problem can be a valuable discovery, it can be of countervalue if it fails to address its relation to the dominant power structure. Even more problematic, in fact, are those studies portraying smuggling activities as 'a crime against humanity', for instance, in Libya because they completely leave unaddressed the responsibility of Western capital in producing these outcomes and the very securocratic mechanisms being taken against them. ${ }^{40}$ By calling for a renewed 'humanitarian' engagement from the international community against smugglers, these studies fail completely to consider how the same international forces perpetuate these conditions.

In a similar vein, when engaging the question of precarity and informality in Tunisia, liberal political economy traces it in relation to processes of state capture and cronyism, emerging as forms of late-development syndrome and/ or unfair market-competition in the country. By centring the role of capital and class, the next section lays out a conceptual critique and calls for the need to rethink state capture vis-à-vis the global neoliberal economy.

36 Schröder, C. "World Social Forum in Tunisia 2013 and 2015 - Reflections and Expectations." Rosa-Luxemburg-Stiftung (2014), available online at https://www.rosalux. de/en/publication/id/7766/world-social-forum-in-tunisia-2013-and-2015-reflections-andexpectations/ (accessed 28 January 2021).

37 Capasso, M. "The war and the economy: The gradual destruction of Libya." Review of African Political Economy 47 (166) (2020), 545-567.

38 Brachet, "Manufacturing Smugglers"; Sanchez, 'Women's Participation in the Facilitation of Human Smuggling'; Keen, D. and R. Andersson. "Double Games: Success, Failure and the Relocation of Risk in Fighting Terror, Drugs and Migration" Political Geography 67 (2018), 100-110.

39 Pradella, L. and R. Cillo. "Bordering the Surplus Population across the Mediterranean: Imperialism and Unfree Labour in Libya and the Italian Countryside" Geoforum (2020), DOI 10.1016/j.geoforum.2020.06.019.

40 Kuschminder, K. and A. Triandafyllidou. "Smuggling, Trafficking, and Extortion: New Conceptual and Policy Challenges on the Libyan Route to Europe." Antipode $5^{2}$ (1) (2020), 206-226. 
When mainstream analyses focus on the nature of the progressive informalization and pauperisation of the Tunisian economy, they often stress and link it to the issue of state capture. ${ }^{41}$ Their main argument lies in demonstrating how political authorities pursue policies that allow them to receive favours with great economic value. In order to capture the state, private and public actors collude and rely on the systematic abuse of formal institutions in order to accumulate power and wealth. Like many other states in the MENA, Tunisia's political economy is described as based on deals between political and economic elites rather than on the enforcement of clear and impartial rules. ${ }^{42}$ Clement and Springborg, ${ }^{43}$ for instance, have argued that politics has driven economic development in the MENA. They outline a dialectic of globalization and colonization where 'third moment' elites adapted to American hegemony in new ways when old elites had to choose between accepting or resisting such hegemony. Governance in the region has varied with states dominating the economy via socialist rhetoric and/or patronage relationships. In their analysis, the room for capital accumulation by the private sector has ranged from very limited in the case of so-called "bunker states" (Algeria, Iraq, Libya, Sudan, Syria, Yemen) to limited in "bully praetorian states" (Egypt, Tunisia, Iran) to substantial in the "globalizing monarchies" (GCC, Jordan, Morocco), while only the "precarious democracies" in the region have granted more far-reaching autonomy to private sector actors (Lebanon, Israel, Turkey). As per Tunisia, they emphasise how the political elites have not allowed its population to benefit fully from the process of economic globalization, distorting the inherent degree of dynamism of a market-oriented society. Instead, they opted for the creation of what Springborg, for example, defines as "limited access orders"; that is "systems in which order is based on political elites appropriating for themselves privileged control over parts of the economy, each getting some share of the rents." 44 Alternatively, as another analyst argues, "the problem was that the private sector in its true sense - the independent, entrepreneurial class outside the clutches of the state-was either non-existent or weak

\footnotetext{
41 Rijkers, B., C. Freund, and A. Nucifora. All in the Family: State Capture in Tunisia (Washington, DC: World Bank, 2014).

42 Diwan, I. and A. Malik and I. Atiyas eds. Crony Capitalism in the Middle East: Business and Politics from Liberalization to the Arab Spring. (Oxford: Oxford University Press, 2019).

43 Moore, C.H. and R. Springborg. Globalization and the Politics of Development in the Middle East (Cambridge: Cambridge University Press, 2010).

44 Springborg, R. Political Economies of the Middle East and North Africa (Cambridge: Polity, 2020), 62-63.
} 
and limited."45 Ultimately, mainstream analyses argue that the roll-back of the MENA state in is linked to a failing process of liberalization, inducing corruption and poor governance.

Against this backdrop, I argue that such interpretations fail to link the pauperization of the national economies of countries in the Global South as constitutive to the global primacy of Western capital. On a theoretical level, their argument is based on three interrelated and faulty assumptions. First, these mainstream interpretations follow the prevalent policy message, according to which economic development depends primarily on the creation of an enabling environment for the private sector, free markets and good governance. ${ }^{46}$ Development advances when these conditions prevail. Therefore, the faulty conditions of state capture in Tunisia and the Arab state at large are symptomatic of weak institutional development, thus late-developmental syndrome. These assumptions emerge clearly in the World Bank study on state capture in Tunisia, which identifies state's abuse of regulation as the main cause of market distortion, thus inequality, in the country. ${ }^{47}$ Second, these interpretations detach the political economy of the MENA region from the wider inter-state imperialist system. In other words, the social formation of the ruling class in the so-called Arab state is abstracted from the subordinate integration of the region in the dynamics of the world market and, more importantly, from the process of unequal exchange. ${ }^{48}$ These interpretations come to present Global North actors and financial institutions in a historical or marginal fashion, when explaining the developmental policy outcomes of the MENA states. Historically, as their role is confined to the colonial period or the Cold War interference, after which the rise of the US as a hegemon does not deserve further scrutiny in relation to the power of capital. Alternatively, when the role of the global neoliberal economy and Western domination is considered, it is done in a metrical and marginal way. That is, it is considered as a percentage, a probability or one among many elements influencing the developmental outcome of these states. Therefore, and this introduces the last problematic point, such interpretations

Heydarian, R. J. How Capitalism Failed the Arab World: The Economic Roots and Precarious Future of the Middle East Uprisings (London: Zed Books, 2014), 18o.

46 For an accessible critique of the theory of neoliberalism, see Weeks, J. F. Economics of the 1\%: How Mainstream Economics Serves the Rich, Obscures Reality and Distorts Policy (London: Anthem Press, 2014). He refers to mainstream economics "upholding theory of free market competition as benign" as a mixture between alchemy and chemistry, astrology and astronomy.

47 Rijkers, Freund, and Nucifora, All in the Family.

48 Amin, Unequal Development; Kadri, Arab Development Denied; Lauesen, The Global Perspective. 
provide the necessary policy ground for these same international actors, including the EU and its member states, to devise potential solutions-through the sending of aid based on conditional reforms - in order to improve the failing political-economic institutions.

However, I argue that state capture in Tunisia and the MENA region at large should be understood in relation to capital and class. That is, capital not as a material entity or a rationale mechanism but, as Ivan Mészáros asserts 'a totalising framework of control into which everything else, including human beings, must be fitted, and prove thereby their productive viability, or perish if they fail to do so. ${ }^{49}$ In doing so, the process of capital accumulation does not have nation-state boundaries, but its creation of class-differentiated society takes place in relation to the geopolitical structure. Therefore, the accumulation of capital by the national comprador elites took place via their subordinate integration into the US-led imperial structure, which-in turn-required the informalization and pauperisation of Tunisian working classes. As Kadri ${ }^{50}$ argues, for instance, the gradual de-development of the MENA region largely stems from the consequences of the military-ideological defeat of the project of Arab Socialism that followed the period of national independence in the 195 os and 196os. While the state-led capitalist experience initially provided relatively prosperous results for the population in the aftermath of colonization, ruling elites not only dropped their egalitarian policies, but became comprador classes of global financial capital, establishing a necrotrophic relationship with the national resources of their countries. While the historical path of Tunisia differed slightly, ${ }^{51}$ it nonetheless witnessed a subordinate integration of its economy into the world market. Therefore, state capture is not the result of a failed or perverted program of economic reforms that many states in the MENA undertook, rather it is the outcome of these same neoliberal reforms that aimed at the gradual

49 Mészáros, I. Beyond Capital: Toward a Theory of Transition (London: Monthly Review Press, 2000), 41.

$50 \quad$ Kadri, A. The Unmaking of Arab Socialism (London: Anthem Press, 2016); Kadri, A. A Theory of Forced Labour Migration: The Proletarianisation of the West Bank Under Occupation (1967-1992) (Singapore: Springer, 2020). Bourguiba to Ben Ali (London: Palgrave Macmillan, 1999); Radl, S. "Structural Adjustment in Tunisia: The Crisis of Neoliberalism and the 'Gafsa Riots' of 2008." In Development by Free-Trade? eds. G. Baumgratz, K. Chaabane, W. Ruf and W. Telkämper (Wien: Peter Lang, 2017), 109-130; Ajl, M., S.A. Haddad and Z. Abul-Magd. "State, Market, and Class: Egypt, Syria, and Tunisia." In A Critical Political Economy of the Middle East and North Africa eds. J. Beinin, B. Haddad and S. Seikaly (Stanford, CA: Stanford University Press, 2020), 46-67. 
incapacitation of the Arab state and the loss of its political autonomy over economic policies.

As the next section argues, the introduction of neoliberalism in Tunisia established structural hierarchies of power beneficial to Western capital, mediated by a local ruling class. This, in turn, could only take place via a progressive aggression upon Tunisian working classes, which then led to the 2011 revolt.

\section{$4 \quad$ Recentring Neoliberalism in Tunisia}

While the liberalization of the Tunisian economy began slowly under Bourguiba, its full implementation coincided with the rise to power of the Ben Ali regime from the late 1980s. Promoting standard policies of liberalization, deregulation, and privatization, IFIs publicised Tunisia's implementation of Structural Adjustment Programmes (SAPs) to boost its economy, aiming to integrate the country into the circuits of international capital. The process, however, came with highly disruptive consequences for the country.

First, Tunisia's economic liberalization created a structural dependence on the European market. Claiming to improve industrial and agricultural exports, the EU and IFIs progressively exploited the 'comparative advantages' - largely meaning cheap labour - of Tunisia in several sectors. In doing so, the export sector came to be based mainly on low-wage labour, consisting of low-value added manufacturing, low-cost tourism and cheap services, while relying on Europe for the import of heavy machinery and technology. ${ }^{52}$ Under these conditions of unequal exchange, economic liberalization also translated into a further entrenchment of Tunisia's food dependence, since the political lexicon concerning the objectives of agricultural policy changed dramatically from the end of the 1980s. The integration of Tunisia's agriculture into the global market created a structural food dependence and a general impoverishment of the peasantry, unable to supply its own food security. ${ }^{53}$ This shift was based on the reorientation of agricultural, economic and natural resources to the benefit

$5^{2} \quad$ Radl, "Structural Adjustment in Tunisia"; Kaboub, F. "The Making of the Tunisian Revolution." Middle East Development Journal 5 (1) (2013), 1-21; Murphy, E. "Under the Emperor's Neoliberal Clothes! Why the International Financial Institutions Got It Wrong in Tunisia." In The Making of the Tunisian Revolution: Contexts, Architects, Prospects. ed. N. Gana (Edinburgh: Edinburgh University Press, 2013), 35-57.

53 Ayeb, H. and R. Bush. Food Insecurity and Revolution in the Middle East and North Africa: Agrarian Questions in Egypt and Tunisia (London: Anthem Press, 2019). 
of investment in agribusiness, promoting the interests of those who benefitted from state investment in irrigation to the detriment of family farming. ${ }^{54}$ Far from being a simple political slogan, those policies produced large-scale changes. Tunisian agricultural strategy no longer focused on producing more for those in need but became instead a strategy to produce more to export. ${ }^{55}$ By looking at Tunisia's agricultural map, we can see how agricultural production is geared towards meeting export-oriented 'free trade' objectives, rather than supporting food sovereignty for its people. ${ }^{56}$

Moreover, both the EU and IFI s did not refrain from supporting the adoption and promotion of legislative and economic measures that, while pushing for privatization, led to a massive deterioration in the conditions of workers. Radl, ${ }^{57}$ for instance, notes how the EU contributed to building an industrial textile and clothing sector that failed to regulate the employment of workers by supporting the creation of Special Economic Zones (sEz, Parcs d'Activités Economiques), in which the normal labour code was invalid. In the aftermath of 2011, the wв published a study ${ }^{58}$ criticizing the Investment Incentives Code (ICC), giving it as one of the main reasons for the perverted process of state capture in Tunisia. The same шв had not only participated actively in its formulation, but also made its $\$ 250$ million 1991 Economic and Financial Reforms Support Loan (EFRSL) conditional on its adoption. ${ }^{59}$ According to the WB, the rentierization of the economy took place because Ben Ali was taking advantage of regulation to protect his clan; that is, the state intervened 'too much' in the economy. However, a report from the Observatory of the Tunisian Economy shows how the main problem lied in the realm of incentives provided to firms through the manipulation of decrees. ${ }^{60}$ This is a fundamental issue to highlight because it reveals how IFIs were not only complicit in the adoption of the ICC, as discussed above, but continue to misrepresent the reasons that

54 El Safi, E. "Tunisia's Negligence of Small Farmers Is Creating a Food Crisis." Open Society Foundations (2 November 2016).

55 Ayeb and Bush, Food Insecurity and Revolution in the Middle East and North Africa, 93-122.

56 Hamouchene, H. and L. Riahi. Deep and Comprehensive Dependency: How a Trade Agreement with the EU Could Devastate the Tunisian Economy (Amsterdam: Transnational Institute, 2020).

57 Radl, "Structural Adjustment in Tunisia."

$5^{8}$ Rijkers, Freund, and Nucifora, All in the Family.

59 Aliriza, F. "Perpetual Periphery: IFIs and the Reproduction of Tunisia's Economic Dependence." In The Impact and Influence of International Financial Institutions on the Economies of the Middle East and North Africa. ed. T. Radwan (Tunis: Friedrich Ebert Stiftung, 2020), 26-41.

6o Ben Rouine, C. 'All in World Bank': Manipulation in the Name of Deregulation (Tunis: Tunisian Observatory of Economy, 2016). 
allowed Ben Ali and its clan to rule. By focusing on regulation-rather than incentives, these policy studies ultimately aim "to break down what remains of the Tunisian state capacity to direct investment policies." ${ }^{n 1}$ Overall, while these changes deepened the country's ties with the European market, they also increased its trade balance hugely, and thus public debt. As of 2018, debt service repayments were expected to reach a record $22 \%$ of the country's budget. ${ }^{62}$

This process could only take place in collaboration with a class of national comprador elites that, having abandoned their egalitarian agenda, came to monopolise national resources and wealth. In such a scenario, it is possible to understand how the introduction of market forces allowed the Ben Ali clan to consolidate the process of state capture. ${ }^{63}$ Through liberalization, regime elites were slowly incorporated into an international capitalist class, ${ }^{64}$ although "they were on the margins of network power, in that they extracted rent from the circulation of capital (into and out of Tunisia) rather than being at its productive heart." 65 In other words, the political economy of Tunisia was erected around structural hierarchies of power beneficial to the Western capital, yet necessitating the support of the ruling class.

Consequently, on the one hand, the formal sector remained under the control of rent-seeking elites who reaped the benefits of opening the economy to international capital, which significantly affected the distribution of wealth and power within and among the local population. By the end of the 199os, the inner circles around Ben Ali and his wife Leila Trabelsi ${ }^{6}$ started to control investments and private projects. ${ }^{67}$ The Trabelsi-Ben Ali clan created

$61 \quad$ Ibid., 2.

62 Chandoul, J. "The Imf Has Choked Tunisia. No Wonder the People Are Protesting." The Guardian (17 January 2018).

63 Tsourapas, G. "The Other Side of a Neoliberal Miracle: Economic Reform and Political De-Liberalization in Ben Ali's Tunisia." Mediterranean Politics 18 (1) (2013), 23-41; Kaboub, F. "The End of Neoliberalism? An Institutional Analysis of the Arab Uprisings." Journal of Economic Issues 47 (2013), 533-544; Brésillon, T. "En Tunisie, l'économie de rente a été plus forte que les idéaux de la révolution." Middle East Eye (9 June 2020).

64 Ajl, M. "Development by Popular Protection and Tunisia: The Case of Tataouine." Globalizations 16 (7) (2019), 1215-1231.

65 Murphy, E. "A political economy of youth policy in Tunisia." New Political Economy 22 (6) (2017), 683.

66 Kchouk, B. "Les « anciennes » élites économiques et le changement de régime en Tunisie: de l'incertitude vers la consolidation politico-économique des positions." Politix 120 (4) (2017), 157-178.

67 Santini, R. H. Limited Statehood in Post-Revolutionary Tunisia: Citizenship, Economy and Security (London: Springer, 2018). 
a "networks of privilege" 68 system through alliances-i.e., marriages-and obedience-i.e., by controlling business associations or sanctioning voices of dissent-in order to consolidate their position. ${ }^{69}$ Ben Ali's clan managed to establish a vast and lucrative business empire, capturing the state through a process of aggressive privatization accompanied by tax evasion and capital flight. As in other Arab republics, the ruling class established a necrotrophic relationship with national resources. That is, the ruling elites began to enrich themselves through rent-seeking and parasitic commercial activities, systematically transferring their wealth abroad, instead of investing in national or regional enterprises. For instance, in the case of the automobile market, the family first appropriated public firms through privatization, and the connected firms subsequently experienced a policy-induced surge in demand while evading import taxes. ${ }^{70}$ The Ben Ali clan and its affiliates operated in multiple sectors, including telecommunications, air transport and real estate.

The gradual capture of the state on the other hand, triggered the increasing informalization of the economy, including the rise in smuggling activities in the long-neglected regions of the South. As Santini argues, the emergence of the informal economy did not reflect an attempted but unsuccessful state penetration in some regions and policy arenas. Rather, its origin and flourishing "epitomizes a rational decision by the Tunisian central authority to concentrate investment and resources in areas more economically developed and politically more loyal." ${ }^{21}$ In the years preceding the uprising of 2011, clientelist networks gained total control of the job market, creating a system of distribution of resources that only increased the economic divide between the North and South of the country, as well as the coastal and interior zones. ${ }^{72}$ Those differences emerged clearly in the imbalance of economic and social reforms and developmental policies that the state implemented predominantly in the coastal areas and the capital, Tunis, and effectively led to the marginalizing of other regions. Such disparities led to several rounds of popular protests and mobilisation, as was the case of the Gafsa revolt. For instance, in the 20 years following the restructuring of the economy in 1985, 10 ooo jobs were suppressed

68 Heydemann, S. Networks of Privilege in the Middle East: The Politics of Economic Reform Revisited (New York, NY: Palgrave Macmillan US, 2004).

69 Arouri, H. and L. Baghdadi, and B. Rijkers. "State Capture in Ben Ali's Tunisia" In Crony Capitalism in the Middle East eds. I. Diwan, and A. Malik and I. Atiyas (Oxford: Oxford University Press, 2019), 173-204.

70 Kchouk, "Les « anciennes » élites économiques et le changement de régime en Tunisie."

71 Santini, Limited Statehood in Post-Revolutionary Tunisia, 63.

72 Meddeb, H. Peripheral Vision: How Europe Can Help Preserve Tunisia's Fragile Democracy (Brussels: European Council for Foreign Relations, 2017). 
with dramatic effects on job creation and youth in the region. ${ }^{73}$ The revolt in the Gafsa mining basin was sparked by a fraudulent recruitment procedure organized by the Gafsa Phosphates Company (GPC) in January 2008, which offered coveted jobs in mines re-opened by the government to young candidates from outside the region and connected to the regime, to the disadvantage of the local population. Jobs, in fact, would be distributed among local patrons and regional administrations according to a quota system. In turn, the latter would redistribute these jobs among their clients on a tribal or partisan basis, or even sell them to the highest bidder. ${ }^{74}$ While this system of redistribution of resources was delicately implemented over two decades in the Tunisian periphery, it also fuelled the fragmentation of local society, consolidating tribal identities and social grievances. ${ }^{75}$ In addition, local residents were left with environmental damage that, in turn, affected agricultural production, another important source of income. ${ }^{76}$

It is important to note that, under the regime of Ben Ali, international institutions praised and applauded Tunisia for its implementation of SAPs. By relying on the progress of macroeconomic indicators, i.e., economic growth and poverty reduction, Tunisia seemed to enjoy an annual average gross domestic product (GDP) growth rate of $5 \%$ between 1997 and 2007, and experienced a strong recovery following the 2008 global recession and a $3.7 \%$ GDP growth in 2010. In that same year, the World Bank went as far as praising the country for its remarkable progress on equitable growth, fighting poverty and achieving good social indicators. ${ }^{77}$ The façade of macroeconomic indicators as a threshold for social development only mirrored the capacity of the regime to devise a discourse of reformism that, while relying on practices of domination and coercion, was heavily invested in a language of negotiation and fighting against corruption..$^{78}$ The latter emphasized the tradition of 'listening' on the part of Tunisian officials and highlighted the consensus around liberalism with a dash

73 Allal, A. "Neoliberal reforms, clientelism, and protest in a political authoritarian context: Social movements in the Gafsa mining area of Tunisia in 2008" Politique Africaine 117 (1) (2010), 107-125.

74 Meddeb, Peripheral Vision.

75 Ibid.

76 Ghilés, F. and E. Woertz. "Tunisian Phosphates and the Politics of the Periphery" In Environmental Politics in the Middle East ed. H. Verthoeven (Oxford: Oxford University Press), 53-74.

World Bank. Tunisia - Development Policy Review: Towards Innovation-Driven Growth (Washington, DC: World Bank, 2010).

78 Hibou, B. The Force of Obedience: The Political Economy of Repression in Tunisia (Cambridge: Polity, 2011). 
of attention given to the social sphere-in other words, cosmetic changes. European officials left this process completely untouched, actively sustaining the regime's survival and enrichment through the use of coercive control over the political apparatus and wider society. ${ }^{79}$ IFI policy recommendations are hailed as prudent and wise, yet the primary beneficiaries have always been the political elites and other well-connected, wealthy Tunisians. For instance, the son-in-law of Ben Ali purchased a $17 \%$ share of a bank just before it was to be privatized and then sold the shares at a premium. ${ }^{80}$ Therefore, those policies not only fail to improve the life of Tunisians, but also are doomed to find local opposition and resistance.

In fact, the progressive deterioration of socio-economic conditions encouraged societal discontent, playing a significant role in fanning the flames of the 2011 popular protests. A small incident blew up into a huge popular uprising that resulted in the ousting of Ben Ali on 14 January 2011, less than a month after mass demonstrations had begun. The story of Mohamed Bouazizi, who set himself on fire, emblematically captured the experiences of frustrations, humiliations and lack of respect that many Tunisian faced vis-à-vis public authorities. This event became a turning point of incandescence, where Tunisians coalesced across the country in a call for restoring their dignity vis-à-vis the corrupt regime of Ben Ali. ${ }^{81}$ Therefore, the immolation of the young fruit-street vendor triggered 'different spatially-disconnected social classes to converge into a national revolt,'82 thus emerging as a unified political actor, because dignity was a collective demand. ${ }^{83}$ In this regard, the long history of activism and organizational culture of UGTT (Tunisian General Labour Union) played a key role in coordinating the various forces and movements at work across the country, thus hastening the fall of the regime. ${ }^{84}$ At the same time, there is a need to move beyond the power-resistance dichotomy positing 'the people versus the regime,'

Hibou, B., H. Meddeb and M. Hamdi, Tunisia after 14 January and Its Social and Political Economy: The Issues at Stake in a Reconfiguration of European Policy (Brussels: EuroMediterranean Human Rights Network, 2011).

$80 \quad$ Wikileaks. "Corruption in Tunisia: What's Yours Is Mine." Wikileaks, available online at https://wikileaks.org/plusd/cables/o8TUNIS679_a.html (accessed 26 April 2020).

81 Hibou, B. and S. Khiari. "«La Révolution tunisienne ne vient pas de nulle part»" Politique africaine 121 (1) (2011), 23-34.

Middle East Centre Oxford. Webinar: Sami Zemni -The Trajectory of the Tunisian Revolution (13 November 2020), available online at https://www.youtube.com/ watch?v=9bSvvGlkaeo\&t=2065s (accessed 12 February 2021).

83 Ayeb, H. "Social and Political Geography of the Tunisian Revolution: The Alfa Grass Revolution" Review of African Political Economy 38 (129) (2011), 467-479.

84 Yousfi, H. Trade Unions and Arab Revolutions: The Tunisian Case of UGTT (London: Routledge, 2017). 
and recenter these events in relation to the trasnational character of capital. ${ }^{85}$ In fact, while Tunisia experienced a very significant social upheaval, driven in large measure by structural vulnerabilities related to social, economic, and political exclusion, this took place — as discussed above — after three decades of neoliberal reforms. In a poll conducted after the revolt, most of the respondents believed that the uprising had been induced by youth ( $96 \%)$, the unemployed $(85.3 \%)$, and the disadvantaged $(87.3 \%) .{ }^{86}$

After 2011, Tunisia continued to be praised as a successful revolutionary story. However, despite such international praise, the status quo has largely remained the same. Economic elites have further entrenched their position by hijacking the transition process, and unemployment, particularly youth unemployment, is on the rise (Schaefer 2018). In other words, the structural vulnerabilities characterising Tunisia under Ben Ali have not disappeared. The transitional government seized the assets of the Ben Ali affiliated-clan, resulting in several prosperous state-linked companies being sold in a call for tender opened up to local investors. While on the surface this suggested a re-structuring of the political economy, the power relations underpinning Tunisia's economic hierarchies have not shifted significantly, and much-needed changes in job creation and the conditions of access to the labour market are still lacking.

For example, according to the Egyptian think tank Economic Research Forum, three car dealerships previously under the control of the Ben Ali clan were seized and purchased through an auction by factions of the extant business elite. ${ }^{87}$ Indicative examples of this process are how two notable businessmen, Poulina and Ben Yedder, bought the majority shares in the holding company Ennak, while Bouchamaoui and Chabchoub became the new main shareholders of City Cars, while the Loukil group bought the company Ennakl Vehicules Industriels. ${ }^{88}$ In order to understand the unchanging nature of Tunisia's economy post-2011, it is also fundamental to stress that neoliberal reforms and SAP s have continued to be pushed by various coalitions governments. ${ }^{89}$ The Ennhanda-led budget in 2013, for instance, was formulated on a logic of austerity, including a regressive tax policy, cuts on social spending,

85 Bogaert, K. "Contextualizing the Arab Revolts: The Politics behind Three Decades of Neoliberalism in the Arab World" Middle East Critique 22 (3) (2013), 213-234.

86 World Bank. Tunisia: Breaking the Barriers to Youth Inclusion (Washington, DC: World Bank, 2014).

87 Oubenal, M. and H. Ben Hamouda. The Political Economy of Business Elites in Tunisia: Actors, Strategies and Identities, (Cairo: Economic Research Forum, 2018).

$88 \quad$ Ibid., 16.

89 Erol, M.E. “From Dictatorship to 'Democracy': Neoliberal Continuity and Its Crisis in Tunisia." New Middle Eastern Studies 10 (2) (2020), 147-163. 
and no significant increase in wages. While Tunisian ruling classes continue to insist on the implementation of neoliberal reforms backed by the IMF and other international creditors, rent-seeking elites continue profiting vis-à-vis the global economy. In this regard, tax evasion provides an important example. By way of illustration, in 2018, employees paid 5488.4 million dinars in taxes, double the amount paid by the companies that employ them (i.e., 2713.8 million dinars). Furthermore, oil companies only contributed $4 \%$ of total tax revenue, despite generating very large profits..$^{90}$ The issue of tax evasion shows the links between national wealth and global capital: Tunisia has been ranked fifty-ninth ${ }^{91}$ among countries with the largest sums of money hidden in the accounts of Swiss banks, comprising more than $\$ 5^{2}$ million and 256 customers. ${ }^{92}$ Among these customers it is possible to identify the same names of the families of the large groups mentioned above, but also the names of the ex-first lady, the Trabelsi family. The Panama Papers instead show how big industrial tycoons operate offshore accounts, and the documents include the names of, for instance, Raouf Bouchamaoui, whose business operations range across oil and gas, real estate, and financial services. ${ }^{93}$

Moreover, the collapse of family farming has led to a considerable increase in unemployment and to an exodus of young people from rural areas into cities, where there is no work for them, and where informal work, including the facilitation of smuggling, is considered as an alternative. ${ }^{94}$ Joining the informal sector, which does not provide the basic conditions to safeguard workers (health insurance, social protection, union rights, etc), becomes a question of necessity and survival, it is hardly a choice. ${ }^{95}$ Young people tend to opt for jobs in the informal sector-even if seasonal (tourism) or risky (smuggling)—because

$90 \quad$ Ben Abderrazek, M. "Tunisie : L'impôt sur les sociétés pétrolières ne dépasse pas $4 \%$ du total des recettes fiscales..." Tunisie Numerique (26 February 2020), available online at https://www.tunisienumerique.com/tunisie-limpot-sur-les-societes-petrolieres-nedepasse-pas-4-du-total-des-recettes-fiscales/ (accessed 8 May 2020).

It is also the first Arab country in terms of illicit financial flows, which represents $16.2 \%$ of its non-oil trade, see Ben Rouine, C. Tunisia : First Arab Country in Terms of Illicit Financial Flows. (Tunis: Tunisian Observatory of Economy, 2019).

Sbouai, S. and K. Khadharaoui. "Swiss Leaks : Que révèlent les listings tunisiens ?" inkyfada, February 8, 2015.

93 Ben Hamadi, M., S. Sbouai, and K. Khadharaoui. “\#PanamaPapers : Mzabi et Bouchamaoui dans les rouages du système offshore." inkyfada (9 May 2016).

94 Amayed, A. "Food Security in Tunisia: A Need to Move Back to Sovereignty" Observatoire de la Souveraineté Alimentaire et del'Environnement (14 May 2020), available online at https://osae-marsad.org/2020/o5/14/food-security-in-tunisia-a-need-to-move-back-tosovereignty/ (accessed 28 January 2021).

95 International Labour Organization. "La jeunesse tunisienne et l'économie informelle." (2015), available online at http://www.ilo.org/employment/areas/youth-employment/ 
they are the ones paying the most. Tourism, one of the most important sectors of Tunisia's economy, is built on structurally precarious contracts that barely involve registration for social security. However, the salaries gained in a few months can be more than the average salary of the private sector over a year. ${ }^{96}$ As of 2020, the informal sector represents nearly $40 \%$ of the country's GDP and $32 \%$ of total employment, yet experiencing a major drop due to the restrictions on tourism and local markets imposed by the government to fight the pandemic. ${ }^{97}$

At this critical juncture, as the EU has launched the new Migration Pact, and popular protests have begun again on the occasion of the tenth anniversary of the 2011 uprising, it is vital to reflect on the consequences of these policies and the prospects for the country.

\section{5 \\ Free Trade and Security: Serving Capital, Securitising Poverty}

In line with the work of other scholars in the region, ${ }^{98}$ I argue that the participation of people in the facilitation of human smuggling has become increasingly framed as a criminal and illegal practice, mirroring EU attempts and initiatives to curtail irregular migration. More importantly, I showed that such securocratic narratives and policies align with liberal political economy analyses presenting the socio-economic maladies of countries of the Global South as internal problems due to late-developmental syndrome. As long as these issues are rendered legible through a security lens or weak governance on the level of the EU, the responsibilities of Western capital will stay concealed. These analyses only allow fashioning a discourse on Tunisia's condition-and the Global South, at large - that internalises the causes of crisis and normalises the politics through which the country is produced as an object of Western colonial fantasy and capital extraction. ${ }^{99}$ Against this backdrop, I traced the discussion on the facilitation of human smuggling and state capture to the process of unequal exchange. In fact, as much as precariousness of labor and

WCMS_444912/lang--fr/index.htm (accessed 26 April 2020); Trabelsi, K. Current State of the Informal Economy in Tunisia as Seen through Its Stakeholders: Facts and Alternatives (Tunis: UGTT, 2014).

96 International Labour Organization, "La jeunesse tunisienne et l'économie informelle."

97 Dridi, M. "Coronavirus and Tunisia's Regional Economic Inequalities" Carnegie Endowment for International Peace (Washington, DC: Carnegie, 2020).

98 Brachet, "Manufacturing Smugglers"; Richter, "Doing Bizness.."

99 Wai, Z. "The Empire's New Clothes: Africa, Liberal Interventionism and Contemporary World Order." Review of African Political Economy 41 (142) (2014), 483-499. 
life drives people's participation in human smuggling, this should be understood vis-à-vis the increasing pauperization of the economies of countries of the Global South, which allows, in turn, Western global primacy to continue. Therefore, the EU has a serious choice to make, which is to continue pressing for the implementation of an aggressive neoliberal agenda or to reconsider its historical and devastating impact on labour, nature and life. Unless questioned, political agendas based on the promotion of resilience, good governance and crisis prevention ${ }^{100}$ will continue to function as umpteenth instruments of EU control.

For instance, as the recent EU-Tunisia talks on agricultural agreements show, Tunisia risks entrenching its dynamic of food dependence. Once again, the EU aims to capitalize on the so-called 'comparative advantage'101 of Tunisia; that is, on the ability of the country's economy to produce a particular good or service at lower costs than other trading partners. However, based purely on an arithmetical understanding of prices and costs, the law of comparative advantage purposedly elides the role of Western capital and imperialist aggression in pauperising the economies of the developing world. In this regard, the comparative advantage of Tunisia lies in its nearly year-round sunshine, which will force the country to shift toward production of fruit and vegetables for export, and cheaper wages. Such an agreement ultimately would only create a dependence on imports for the basic cereals that make up most Tunisian diets. The EU-Tunisia trade liberalization agenda, Deep and Comprehensive Free Trade Agreement (DCFTA), is an emblematic example of the inherent risks in opening up the local economy to global competition without any form of protectionism for local production. This process, in fact, has a tendency to reduce the power of labour exposed to the pressures of global markets and competition, while allowing ruling elites to enrich themselves further. While the agreement brings an increase in Tunisian exports, mainly from the fruit, fish, and olive

100 The EU Global Strategy centres its focus on resilience and the need to strengthen it in neighbouring countries to prevent crises. The EU has defined resilience as "the ability of states and societies to reform, thus withstanding and recovering from internal and external crises" (Ibid.) and made it a key pillar of its policies in the MENA region. See European External Actions Service. “A Global Strategy for the European Union's Foreign and Security Policy" (2016), available online at https://eeas.europa.eu/topics/eu-globalstrategy/17304/global-strategy-european-unions-foreign-and-security-policy_en (accessed 28 January 2021).

101 For a deeper understanding of these dynamics in relation to agriculture or health, see Patnaik, U. and P. Patnaik. A Theory of Imperialism (New York, NY: Columbia University Press, 2017); Valiani, S. Rethinking Unequal Exchange: The Global Integration of Nursing Labour Markets (Toronto, ON: University of Toronto Press, 2012); Emmanuel, A. Unequal Exchange: A Study of the Imperialism of Trade. (New York, NY: Monthly Review Press, 1972). 
oil (previously forbidden) sectors, due to their high competitiveness in the EU market, some agri-food subsectors, mainly animal products, milk and dairy products and cereals, remain unprepared to support the costs of the DCFTA. ${ }^{102}$

Furthermore, the reliance on the EU Twinning instruments has either pushed the Tunisian government to undertake more risk-oriented policies or has been used to subsidize EU 'expertise.' For instance, when carrying out the EU-Tunisian Twinning project 'Support of the National Prevention Plan for Occupational Accidents and Diseases' in 2012-2014, the central purpose of the project was to support the kind of development that pictures good governance as the ability of Tunisian public institutions to administer health in an efficient way by undertaking activities like risk calculation, risk assessment and risk reduction. In other words, the government is encouraged to calculate activity to reduce risks and decrease costs in health matters ${ }^{103}$ in a neoliberal fashion. Similarly, the implementation of Twinning projects in the maritime sectors has functioned as a way to subsidize European expertise and workforce. While the EU has agreed to invest 1.3 million Euros, all the budget is being administered by a European bureau of management, its inspectors and workers, with neither involvement of Tunisian authorities, nor investment in Tunisian infrastructures. ${ }^{104}$ The unquestioning support for neoliberalism is further reflected in how different Tunisian governments have adopted the category of youth as the most relevant analytical framework for the diagnosis of the country's social and economic problems. Failing to link the question of youth to the structural international economy, ${ }^{105}$ its inclusion in the current market-regulated system can only continue to take place under conditions of exploitation. ${ }^{106}$

Under neoliberalism, it should come as no surprise to EU policymakers that pauperised Tunisians participate in informal economies. The essential elements of human smuggling are quite real: poverty, absence of a horizon other than suffering, and the risk of facing death. Overcoming the socio-economic problems of the periphery will be achieved by treating the EU as part of the problem rather than as part of the solution. In this regard,

\footnotetext{
102 Mergos, G. and M. Papanastassiou. Food Security and Sustainability: Investment and Financing along Agro-Food Chains (London: Springer, 2016).

103 İşleyen, B. "The European Union and Neoliberal Governmentality: Twinning in Tunisia and Egypt" European Journal of International Relations 21 (3) (2015), 672-69o. Bouchnak, H. Association Agreement \& EU Technical Assistance Instruments Case Study on the EU-Twinning Project for the Reinforcement of the Maritime Administration. (Tunis: Tunisian Observatory of Economy, 2019).

105 Kadri, $A$ Theory of Forced Labour Migration.

106 Pepicelli, R. and M.C. Paciello. Youth in Tunisia. (Rome: IAI Istituto Affari Internazionali, 2016).
} 
it is not only important to stress how Western countries support 'authoritarian regimes' in the south of the world, but it is also crucial to understand the structural reasons that generate this support. Concerted action is needed to put an end to the neoliberal model of development, and its free-trade agreements requiring Global South states to allow for complete capital repatriation and fiscal-investment policies that benefit foreign capital. There needs to be a push toward a cooperation model based on equal exchange of resources and technologies. This could take place, for instance, through the support of a sustainable agro-ecological model that allows to feed the population of Global South countries, while taking into account the changing climatic conditions. ${ }^{107}$ Concrete measures could also involve tackling the question of tax evasion. Neoliberalism means ever lower taxes for its main winners - the owners of big multinational companies-and ever-higher taxes for those it leaves out-working-class families. ${ }^{108}$ Tax havens, in this regard, are the emblematic example of how capital flight from developing countries to the imperialist core takes place. ${ }^{109}$ Europe has the power to push for a change, rather than continuing to coordinate its neoliberal assault upon Tunisians workers. However, the EU and IFIs have not only remained blind to the popular demands for a rejection of neoliberal policies but have increased the power of the transnational security agenda that operates in tandem with it. ${ }^{110}$

In fact, while the new EU 2020 Migration Pack ${ }^{111}$ has highlighted a fundamental truth, that 'every action has implications for others', too much emphasis continues to be put on crisis management, fighting migrant smuggling and providing border control. The issue of solidarity is mentioned but, once again, in relation to practices of search and rescue, pressure and crisis. The EU commission continues to reiterate the idea that migrants' smuggling is organised

107 Holt-Giménez, E., A. Shattuck, and I. Van Lammeren. "Thresholds of Resistance: Agroecology, Resilience and the Agrarian Question" The Journal of Peasant Studies (2021), DOI 10.1080/03066150.2020.1847090.

108 Saez, E. and Zucman, G. The Triumph of Injustice: How the Rich Dodge Taxes and How to Make Them Pay (New York, NY: W.W. Norton, 2019).

109 Nasirumbi, S. "Taxation, Capital Flight, and Imperialism." In The Palgrave Encyclopedia of Imperialism and Anti-Imperialism, eds. I. Ness and Z. Cope (Cham: Springer International, 2019).

110 Mullin, C. and I. Patel. "Governing Revolt: EU-North African Relations after the 'Arab Spring' Uprisings." Journal of Intervention and Statebuilding 9 (2) (2015), 162-189.

111 EU. Migration and Asylum Package: New Pact on Migration and Asylum Documents Adopted on 23 September 2020 (2020), available online at https:/ec.europa.eu/info/publications/ migration-and-asylum-package-new-pact-migration-and-asylum-documents-adopted-23september-202O_en (accessed 25 January 2021). 
through criminal networks: "Too many people risk their lives by attempting to enter the EU irregularly, fuelling a smuggling industry that is ruthless, criminal and destabilising to local communities. The threats of terrorism, organised crime and corruption continue to feed instability and stifle prosperity."112 As such, the EU remains committed to "step up common efforts to combat trafficking and fight the criminal networks behind migrant smuggling and trafficking in human beings,"113 and migration governance and externalization of border management are crucial tenets of this strategy.

In this regard, I argue that the pauperisation of Tunisian workers should be read in the wider geopolitical context of war and destruction in North Africa, particularly in relation to Libya and the Sahel. In other words, the merging of neoliberalism and security is becoming a new way to articulate the Global South in the global economy. The importance of the informal economy in Tunisia has only increased since 2011, also attributable to the end of migration to Libya. Since the gradual destruction of Libya, ${ }^{114} 40$ ooo Tunisian workers have left Libya. ${ }^{115}$ For more than four decades Libya was a major destination for Tunisian seasonal workers and the loss of these incomes has increased poverty and dissatisfaction among large swathes of the population: 10 ooo15 ooo families ${ }^{116}$ have received no income since 2011 because of the crisis in Libya. ${ }^{117}$ However, when the wB discusses the impact of the Libyan crisis on Tunisia, it mainly points out how "investors are risk averse and their risk aversion is heightened during a security crisis, as civil insecurity creates economic uncertainty and thus is an important risk factor" to understand the decreasing

112 European Commission. "Joint Communication to the European Parliament, the Council, the European Economic and Social Committee and the Committee of the Regions. Renewed partnership with the Southern Neighbourhood A new Agenda for the Mediterranean" (9 February 2021), available online at https://eur-lex.europa.eu/legal-content/EN/ TXT/?uri=JOIN:2021:2:FIN (accessed 15 February 2021), 1.

$113 \quad$ Ibid., 17.

114 Capasso, "The war and the economy."

115 Santi, E., S. Ben Romdhane, and M. S. Ben Aissa. Impact of Libya's Conflict on the Tunisian Economy: A Preliminary Assessment (Abidjan: African Development Bank, 2011).

116 According to a study from IOM and African Development Bank, 40,00o Tunisians worked in Libya before the events of 2011, and they were mostly involved in low-skilled job in the ares of trade, agriculture and industry. For more information, see African Development Bank and International Organization for Migration in Tunisia. "Migration of Tunisians to Libya: Dynamics Challenges and Prospects." African Development Bank - Building Today, a Better Africa Tomorrow (Abidjan: African Development Bank, 2013).

117 Meddeb, H. Precarious Resilience: Tunisia's Libyan Predicament. (Rome: Istituto Affari Internazionali, 2017). 
levels of investments in Tunisia. ${ }^{118}$ What this interpretation leaves out is how the same militarism that creates increasing security has become a sphere of investment and financial profiteering per se, lying at the core of late capitalism's attempt to shape the relations of social reproduction. In this regard, the imperialist assault on Libya has only embedded Tunisia much more into the emerging infrastructure of surveillance, military bases and border control. From the creation of the 125-miles border between Libya and Tunisia undertaken jointly by Germany and the US, or the new EU digital surveillance installation on its coast, 'ISMariS,' 119 Western countries are expanding their military footprint in the region. In October 2020, the US signed a 10-year military cooperation agreement with the Tunisian government. ${ }^{120}$

Contemporary political and research agendas continue to reproduce the prevailing mythology ignoring the context in which migration and its facilitating practices take place and its root causes. After all, state capture or rentierism is not unique to Tunisia, rather it is an ineherent feature of capitalism, and much more embedded in countries of the imperial core. In the US and UK, recent studies have documented how capitalism leads to the inevitable creation of rentier mechanisms, where powerful rentiers engineer ways to commodify politics, while politicians use rental income to indulge in clientelist practices - meaning: lobbying - to stay in office ${ }^{121}$ via processes of financial rentierism. ${ }^{122}$ Consequently, this is a global problem that requires a global solution to alleviate the aggressive progression of neoliberalism. Today's identity politics and increasing economic protectionism is being fuelled by the lack of an internationalist egalitarian platform. Since protectionism and populism are not a substitute for socialist policies at the global level, the only way forward lies in the promotion of an alternative model of development of the productive forces that privilege their use value and is in harmony with nature. ${ }^{123}$

118 Santi, Ben Romdhane, and Ben Aissa. Impact of Libya's Conflict on the Tunisian Economy, 70.

119 See Capasso, M. "War, Capital and the MENA region." POMEPS Studies 42: MENA's Frozen Conflicts (2020), available online at https://pomeps.org/wars-capital-and-the-mena-region (accessed 25 January 2021).

120 Fisayo-Bambi, J. "Tunisia Signs 10-Year Military Deal with US” AfricaNews (1 October 2020).

121 Standing, G. The Corruption of Capitalism: Why Rentiers Thrive and Work Does Not Pay (London: Biteback, 2016).

Christophers, B. "The Rentierization of the United Kingdom Economy." Environment and Planning A: Economy and Space (2019), DOI o.1177/0308518X19873007; Mazzuccato, M. The Value of Everything: Making and Taking in the Global Economy. (London: Allen Lane, 2018). Delgado Wise, R. "Forced Migration and Imperialism in the Neoliberal Era." In The Palgrave Encyclopedia of Imperialism and Anti-Imperialism, eds. I. Ness and Z. Cope (Cham: Springer International, 2019). 
These insights appear to be even more relevant considering the current Covid-19 crisis, as well as the ongoing protests in Tunisia, both of which continue to reveal the depth of the existing social and economic inequality in the country. Lower paid workers involved in informal economies are at a higher risk of becoming infected than the wealthy. They are also exposed to a significantly higher mortality risk because pre-existing medical conditions are unevenly distributed within societies. After more than a week of protests across the country, following a sudden, government-imposed lockdown on the 1oth anniversary of the 2011 protests, security forces have arrested over 1600 people, 600 of them children, according to the Tunisian League of Human Rights. ${ }^{124}$ EU member states, like France, have not hesitated to equip the Tunisian government with armoured police trucks to beat up the protestors. ${ }^{125}$ In such a scenario, it is fundamental to grasp that policies focused on preventing, managing or criminalizing migration do not help to readdress the motivations and structural economic problems that underlie migrant smuggling, its facilitating practices and the wider informalization of the economy. Rather, they are an attempt to criminalise and securitise poverty, while serving the power of capital and furthering neoliberal governance in North Africa.

\section{Acknowledgements}

The article reflects only the author's view, not the European Commission. The latter is not responsible for any use that may be made of the information it contains. Research for this paper has been supported by the Horizon 2020 Research and Innovation Programme of the EU (project "Europe's External Action and the Dual Challenges of Limited Statehood and Contested Orders" (EU-LISTCO)) under grant agreement number 769886 (www.eu-listco.net). My thanks go to Walaa Alqaisiya and two anonymous peer reviewers for their very insightful comments, which guided me through further and important reflections. I am also highly indebted to editor, Immanuel Ness, for his generous support throughout the revision process. Finally, I am very grateful to comrade Gabriella Sanchez from whom I learnt a lot on the world of human smuggling and migration.

124 Ben Mbarek, G. "Families Say Police Abused, Abducted Minors in Mass Sweeps as Protests Continue" Nawaat (25 January 2021).

125 Volkmann, E. "Ten Years on, Tunisians Protest Government, Corruption." Al-Monitor (26 January 2021). 